\title{
Distribution of ring pressure over a worn cylinder liner surface
}

\begin{abstract}
A trial to define the effect of changes in cylinder geometry on compression ring pressure distribution has been presented in this paper which refers to the earlier papers of the authors. The analysis encompasses these cylinders where both circumferential and axial deformations occurred, relative to constructional and assembly errors but above all to engine operation. The conclusions withdrawn from these analyses were applied to exemplary calculations that try to evaluate the effect of cylinder deformation on correct collaboration of ring and liner and particularly on possibility of circumferential gaps leading to blow-by.

The drafts presented in the paper show exemplary results of ring pressure distribution for a complete ring path between the dead centers and selected engine operational data. Moreover, such areas of cylinder surface were shown where slots between compression ring and cylinder liner might occur with high probability.
\end{abstract}

Key words: marine combustion engine, piston ring, ring pressure

\section{Rozkład nacisków pierścienia tłokowego na zużytą powierzchnię gładzi cylindra}

W niniejszym opracowaniu, wiążącym się tematycznie z wcześniejszymi publikacjami autorów, dokonano próby określenia wpływu zmian geometrii cylindra na rozkład nacisku uszczelniającego pierścienia tłokowego. Analizami objęto cylindry, w których wystapity zarówno obwodowe, jak i osiowe zmiany ksztattu, spowodowane np. błędami konstrukcyjnymi i montażowymi, ale przede wszystkim zwiazane z eksploatacja silnika. Wynikajace z tych analiz wnioski wykorzystano do przykładowych obliczeń, obejmujacych ocenę wpływu deformacji cylindra na poprawność wspótpracy pierścienia z gładzia cylindra, a w szczególności na możliwość pojawienia się szczelin obwodowych, ułatwiajacych wystapienie przedmuchów gazów.

Na zamieszczonych w opracowaniu wykresach pokazano przykładowe wyniki obliczeń rozkładu nacisku pierścienia na gładź cylindra, obejmujace cała droge pierścienia pomiędzy punktami zwrotnymi, dla wybranych parametrów pracy silnika spalinowego o ZS. Wskazano również obszary położone na gładzi cylindra, w których wystęuje duże prawdopodobieństwo pojawienia się szczelin pomiędzy gładzia cylindra a powierzchniq ślizgowa pierścienia uszczelniającego.

Słowa kluczowe: silnik spalinowy, pierścień tłokowy, nacisk pierścienia

\section{Introduction}

The piston ring as an element of the piston-cylinder system takes part in providing tightness of combustion chamber during the whole cycle of engine operation. It is widely believed that the ideal tightness occurs when the piston ring touches cylinder liner with its entire circumference (over the oil film). However it is an idealized case possible in initial phase of engine run when collaborating surfaces are still not worn. Along with the period of engine operation these parts are subjected to deformations and wear which eventually lead to the lack of full contact and consequently to loss of combustion chamber tightness and exhaust blow-by.

The position of ring relative to cylinder surface should be determined among others when evaluating phenomena accompanying the ring operation. Forces responsible for ring pressure against the liner, namely ring elasticity force $\mathrm{F}_{\mathrm{s}}$ (Fig. 1) and $\mathrm{F}_{\mathrm{g}}$ force caused by exhaust gases as well as reaction $\mathrm{F}_{\mathrm{f}}$, resulting from oil film pressure should be taken into consideration when defining the ring position.

Deformation and wear of piston-cylinder system parts, as well as the change in their materials properties (loss of ring elasticity, for example) happen during engine run. The form of deformation and its size decisively affect the combustion chamber tightness. Earlier studies of the authors assumed typical

\section{Wprowadzenie}

Pierścień uszczelniający jest elementem układu tłokowo-cylindrowego, który współuczestniczy w zapewnieniu szczelności komory spalania podczas całego cyklu pracy silnika spalinowego. Uważa się, że idealne uszczelnienie występuje wtedy, gdy pierścień osadzony w rowkach tłoka na całym swym obwodzie ma kontakt z gładzią cylindra (poprzez warstwę filmu olejowego). Jest to jednak sytuacja wyidealizowana i ewentualnie możliwa tylko w początkowym okresie eksploatacji silnika, gdy powierzchnie współpracujących elementów nie są jeszcze zużyte. Wraz z eksploatacją silnika elementy ulegają różnego typu odkształceniom i zużyciom, czego efektem może być brak pełnego kontaktu ich powierzchni roboczych, a w rezultacie spadek szczelności komory spalania i wystąpienie przedmuchów gazów spalinowych.

Podczas oceny zjawisk towarzyszących pracy pierścienia określa się m.in. jego położenie względem gładzi cylindra. W trakcie jego wyznaczania bierze się pod uwagę siły powodujące docisk pierścienia do gładzi, a mianowicie siłę sprężystości własnej pierścienia $\mathrm{F}_{\mathrm{s}}$ (rys. 1) oraz siłę $F_{g}$ wywołaną działaniem gazów spalinowych, a także siłę reakcji $\mathrm{F}_{\mathrm{f}}$ wynikająca $\mathrm{z}$ działania ciśnienia w filmie olejowym. 


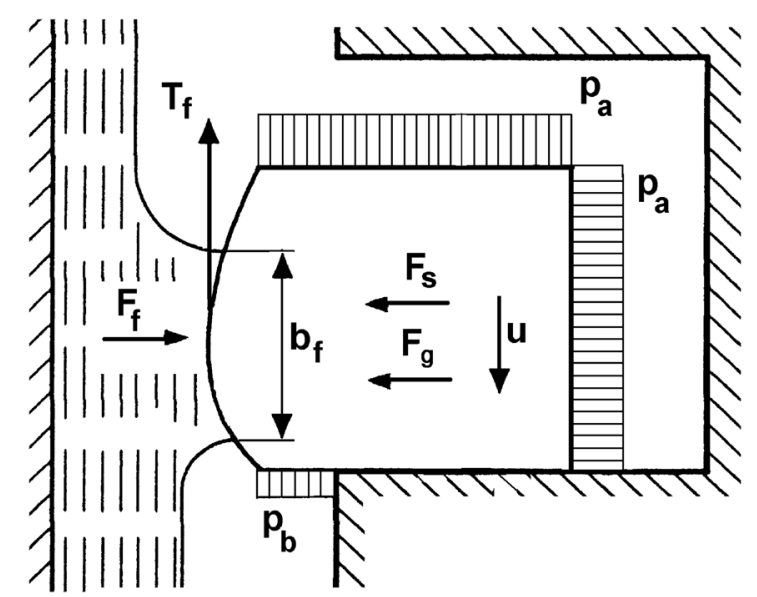

Fig. 1. A sketch of compression ring moving along the cylinder bore; $\mathrm{p}_{\mathrm{a}}$, $\mathrm{p}_{\mathrm{b}}$ - external pressure, $\mathrm{F}_{\mathrm{s}}$ - ring elasticity force, $\mathrm{F}_{\mathrm{g}}$ - force equivalent to gas force affecting a ring, $\mathrm{F}_{\mathrm{f}}$ - oil layer reaction force, $\mathrm{T}_{\mathrm{f}}$ - friction force of ring on oil layer, $\mathrm{u}-$ speed of ring movement, $\mathrm{b}_{\mathrm{f}}-$ ring axial width covered with oil film

Rys. 1. Szkic tłokowego pierścienia uszczelniającego przemieszczającego się względem gładzi cylindra: $p, p_{b}$-ciśnienie zewnętrzne, $F_{s}$ - siła sprężystości własnej, $F_{g}$ - siła równoważna działaniu gazów spalinowych na pierścień, $F_{f}$ - siła reakcji warstwy oleju, $T_{f}$ - siła tarcia pierścienia o warstwę oleju, $u$-prędkość przemieszczania się pierścienia,

$b_{f}-$ wysokość osiowa pierścienia pokryta filmem olejowym

distribution of cylinder wear, namely the maximum value of wear occurs at the upper part of cylinder within the area of ring contact with cylinder at TDC. This phenomenon results from high temperature, high ring pressure and rupture of oil film.

However, beside typical forms of deformation changes in cylinder geometry happen characteristic only for the individual engine. It is commonly believed that individual constructional, materials, technological and assembly properties affect the diversity of cylinder geometry to the greatest extent [3].

The wear of piston rings accompanies the wear of cylinder liner. Due to its own elasticity assisted by external gas forces and thanks to oil film layer the compression ring is able to adjust itself to deformed cylinder and level minor unevenness. Nevertheless, when deviations from cylinder form are too big the circumferential slots occur and eventually exhaust blow-by, and an increased local stress followed by ring breaks [1].

These subjects were analyzed by the authors in their earlier papers, beginning from the case of pure elastic ring pressure against ideally circular and deformed cylinder ending with studies taking into consideration the effect of gas forces as well $[8,9]$. Calculations presented in this paper take into account phenomena accompanying the ring wear process. As in the above mentioned investigations this paper also omits the effect of oil layer over the cylinder surface which means that conclusions require an experimental verification.

\section{Ring contact pressure as a result of elastic and gas forces}

As presented in [9], the circumferential distribution of ring pressure $\mathrm{p}_{\mathrm{m}}(\varphi)$ against the worn and deformed liner can be calculated using following formula:
Pracy układu tłokowo-cylindrowego towarzyszą deformacje i zużycie jego elementów, a także zmiana ich właściwości materiałowych (np. spadek sprężystości pierścienia). Forma odkształcenia oraz jej wielkość mają decydujący wpływ na utrzymanie szczelności komory spalania. We wcześniejszych badaniach autorów tej publikacji przyjmowano typowe rozkłady zużycia gładzi, zakładając, że jego maksymalna wartość pojawia się w górnej części cylindra, w obszarze styku pierwszego pierścienia uszczelniającego z gładzią cylindra w ZZ. Zjawisko to spowodowane jest działaniem w tym obszarze wysokiej temperatury, występowaniem dużych nacisków pierścienia oraz zanikiem filmu olejowego.

Jednak poza typowymi postaciami zużycia pojawiają się zmiany geometrii cylindra charakterystyczne tylko dla danego silnika. Uważa się, że najważniejszy wpływ na zróżnicowanie geometrii cylindra (szczególnie obwodowe) mają indywidualne różnice konstrukcyjne, materiałowe, technologiczne i montażowe [3].

Zużyciu gładzi cylindra towarzyszy zużycie pierścieni tłokowych. Pierścień uszczelniający, w wyniku sprężystości własnej wspomaganej siłami zewnętrznymi (gazowymi) oraz dzięki istnieniu warstwy filmu olejowego, może niwelować niewielkie odkształcenia i dopasowywać się do zmienionego kształtu gładzi. Jeżeli jednak odstępstwa od cylindrycznego kształtu będą zbyt duże, pojawią się szczeliny obwodowe, co prowadzi do zjawiska przedmuchu gazów spalinowych, a także do wzrostu naprężeń lokalnych i pęknięcia pierścienia [1].

Wymienionymi problemami autorzy zajmowali się już w swych wcześniejszych pracach, poczynając od przypadku wyłącznie sprężystego nacisku pierścienia na gładź idealnie kołowego oraz zdeformowanego cylindra [6,7], aż po prace, w których uwzględniano również wpływ sił gazowych [8, 9]. W obliczeniach prezentowanych w tym opracowaniu uwzględniono także zjawiska towarzyszące zużyciu pierścienia. Podobnie jak we wcześniej opisanych badaniach, pominięto wpływ warstwy oleju smarowego pokrywającego gładź cylindra, co powoduje, że wynikające z badań wnioski wymagają doświadczalnej weryfikacji.

\section{Nacisk pierścienia na gladź cylindra pod wpływem sil sprężystych i gazowych}

W pracy [9] wykazano, że obwodowy rozkład nacisku $\mathrm{p}_{\mathrm{m}}(\varphi)$ pierścienia na zużytą i zdeformowaną powierzchnię gładzi cylindra można obliczyć ze wzoru (1),

gdzie, zgodnie z oznaczeniami na rys. 2: E - moduł Younga, I - moment bezwładności przekroju pierścienia, $\mathrm{r}_{\mathrm{m}}$ - promień warstwy obojętnej pierścienia osadzonego w cylindrze, $h_{p}-$ wysokość osiowa pierścienia, $z_{a}-$ zużycie gładzi cylindra, $z_{b}(\varphi)$ - deformacja powierzchni cylindra, zmienna wzdłuż obwodu cylindra (oraz jej druga i czwarta pochodna), $\mathrm{K}_{\mathrm{z}}(\alpha)$ - dynamiczny współczynnik charakterystyczny pierścienia.

Próba oceny rozkładu nacisku na całej drodze pierścienia pomiędzy punktami zwrotnymi, z uwzględnieniem zmian profilu cylindra, wymaga modyfikacji wzoru (1). W wybranej 
a)

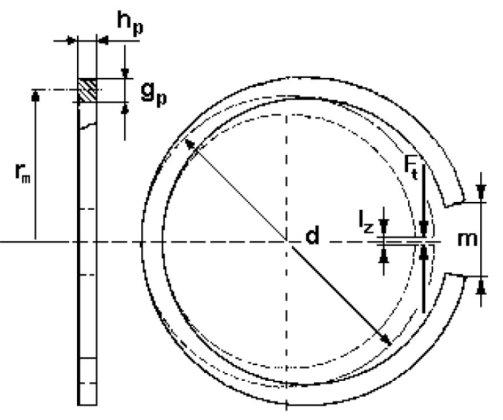

b)

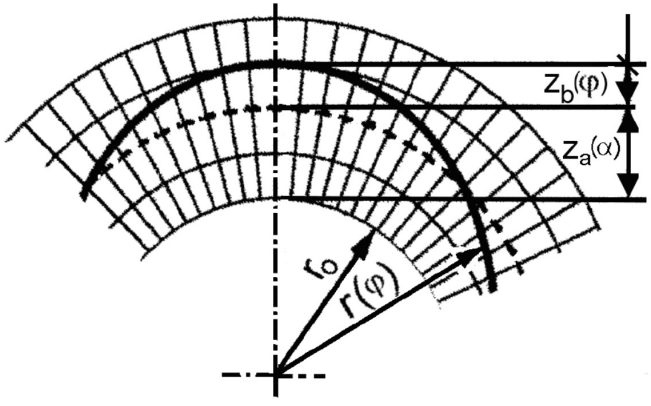

c)

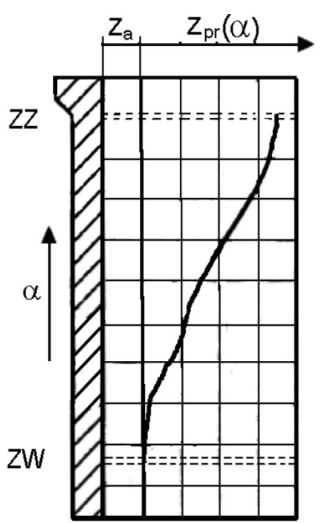

Fig. 2. Sketches of compression ring (a), cylinder segment (b) and cylinder bore profile (c) designated with symbols used in the paper Rys. 2. Szkice pierścienia uszczelniającego (a) fragmentu cylindra (b) oraz profil cylindra (c) z zaznaczonymi symbolami wielkościami stosowanymi w opracowaniu

$$
\begin{aligned}
& \mathrm{p}_{\mathrm{m}}(\varphi)=\frac{\mathrm{E} \cdot \mathrm{I}}{\mathrm{h}_{\mathrm{p}} \cdot \mathrm{r}_{\mathrm{m}}^{4}} \\
& {\left[\mathrm{~K}_{\mathrm{z}}(\alpha) \cdot \mathrm{r}_{\mathrm{m}}-\left(\mathrm{z}_{\mathrm{a}}+\mathrm{z}_{\mathrm{b}}(\varphi)+2 \cdot \mathrm{z}_{\mathrm{b}}^{\prime \prime}(\varphi)+\mathrm{z}_{\mathrm{b}}^{\mathrm{IV}}(\varphi)\right)\right]}
\end{aligned}
$$

where, as in Fig. 2, E - Young's modulus, I - ring cross section moment of inertia, $r_{m}$ - neutral layer radius of ring put into cylinder, $h_{p}$ - axial width of ring, $z_{a}$ - wear of cylinder surface, $z_{b}(\varphi)$ - deformation of cylinder surface, variable along cylinder circumference (and its second and fourth derivative), $K_{z}(\alpha)-$ characteristic dynamic coefficient of ring.

A trial to evaluate the ring pressure over the entire stroke, taking into consideration the variations of cylinder profile, requires a modification of Eq. 1. At the selected plane of cylinder cross section (its location is defined by the crank angle $\alpha$ ) the variations of cylinder radius can be expressed as the difference between initial $r_{\circ}$ and actual $r(\varphi)$ radius, or the sum of wear $z_{a}(\alpha)$ and $z_{b}(\varphi)$ (Fig. 2b)

$$
\Delta r(\varphi)=z_{a}(\alpha)+z_{b}(\varphi)
$$

where element $z_{2}(\alpha)$ means the wear measured at selected plane of cylinder axial cross section, while the element $\mathrm{z}_{\mathrm{b}}(\varphi)$ - its deformation (variation of profile relative to the average line measured along the cylinder circumference).

Deformation of cylinder surface can be expressed as the sum of Fourier series harmonics

$$
\mathrm{z}_{\mathrm{b}}(\varphi)=\sum_{\mathrm{h}=1}^{\mathrm{n}} \mathrm{A}_{\mathrm{h}} \cos \left(\mathrm{h} \varphi+\delta_{\mathrm{h}}\right)
$$

where quantities $A_{h}$ and $\delta_{h}$ are amplitude and phase shift of series consecutive harmonics, respectively. The course of $2^{\text {nd }}, 4^{\text {th }}$ and $6^{\text {th }}$ order harmonics (for exemplary values of harmonics) and their sum was presented in Fig. 3.

The $z_{a}(\alpha)$ wear at certain cross section can be expressed as a sum płaszczyźnie przekroju cylindra (której położenie określone jest kątem $\alpha$ obrotu wału korbowego), zmiany promienia cylindra $\Delta \mathrm{r}(\varphi)$ można wyrazić jako różnicę promieni: rzeczywistego $r(\varphi)$ i początkowego $r_{o}$, względnie jako sumę zużyć $z_{a}(\alpha)$ i $z_{b}(\varphi)$ (rys. 2b) - równanie (2),

gdzie składnik $z_{a}(\alpha)$ wyraża zużycie mierzone w wybranej płaszczyźnie przekroju osiowego cylindra, natomiast składnik $z_{b}(\varphi)$ jego deformację (tak nazwano zmieniające się odchylenie profilu od linii średniej mierzone wzdłuż obwodu cylindra).

Deformację gładzi cylindra można przedstawić jako sumę harmonicznych szeregu Fouriera - równanie (3), gdzie wielkości $\mathrm{A}_{\mathrm{h}} \mathrm{i} \delta_{\mathrm{h}}$ to odpowiednio amplituda i przesunięcie fazowe kolejnych harmonicznych szeregu. Przebiegi harmonicznych 2., 4. i 6. rzędu (dla przykładowych wartości amplitud) oraz ich sumę przedstawiono na rys. 3 .

Zużycie $\mathrm{z}_{\mathrm{a}}(\alpha) \mathrm{w}$ wybranej płaszczyźnie przekroju można wyrazić jako sumę określoną za pomocą równania (4) przy czym $z_{\text {a }}$ oznacza składnik zużycia o stałej wartości, natomiast $z_{p r}(\alpha)$ to składnik zużycia wynikający z przebiegu profilu osiowego cylindra dany wzorem (5)

gdzie $z_{z z}$ i $z_{z W}$ to odpowiednio zużycie gładzi w obszarze górnego i dolnego punktu zwrotnego, $\mathrm{x}(\alpha)$ - przemieszczenie pierścienia odpowiadające kątowi $\alpha$, a $S$ to skok tłoka (rys. 4). Chociaż równanie (5) profilu osiowego cylindra jest tylko przybliżeniem profilu rzeczywistego, to jednak pozwala oszacować wpływ jego przebiegu na rozkład nacisków pierścienia. Podczas wykreślania krzywych przyjęto, że spełniony jest warunek $\mathrm{z}_{\mathrm{zz}} / \mathrm{z}_{\mathrm{ZW}}>10$.

Współczynnik $\mathrm{K}_{\mathrm{z}}(\alpha)$, nazywany dalej dynamicznym współczynnikiem charakterystycznym pierścienia, dany jest wyrażeniem (wg [2]) (6),

gdzie, z niewyjaśnionych wcześniej symboli: $\mathrm{p}_{\mathrm{g}}(\alpha)$ - ciśnienie gazów dociskające pierścień uszczelniający do gładzi cylindra (o wartości zależnej od ciśnienia panującego nad i pod badanym pierścieniem), zmieniające swą wartość w zależności od kąt obrotu wału korbowego $\alpha, \mathrm{K}_{\mathrm{g}}(\alpha)$ - gazowy współczynnik charakterystyczny pierścienia zależny od obciążenia silnika, K - konstrukcyjny współczynnik 


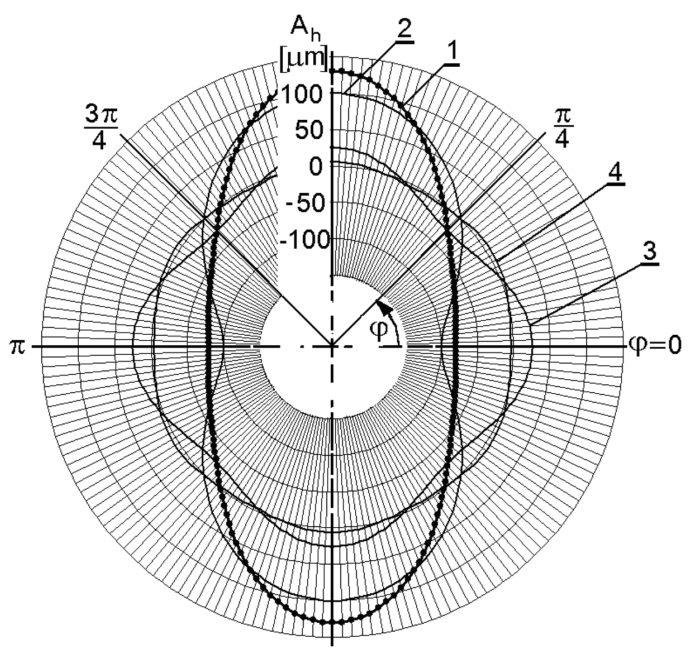

Fig. 3. Course of cylinder circumferential line deviation $\mathrm{z}_{\mathrm{b}}(\varphi)$ from a mean line (curve 1) expressed as a sum of $2^{\text {nd }}$ $(2), 4^{\text {th }}(3)$ and $6^{\text {th }}(4)$ order harmonics drawn for amplitude exemplary values $A_{h}\left(\delta_{h}=0\right)$

Rys. 3. Przebieg odchylenia linii obwodowej cylindra $z_{b}(\varphi)$ od linii średniej (krzywa 1) wyrażonej jako suma harmonicznych 2. rzędu (2), 4. rzędu (3) i 6. rzędu (4), wykreślonej dla przykładowych wartości amplitud $A_{h}\left(\delta_{h}=0\right)$

$$
\mathrm{z}_{\mathrm{a}}(\alpha)=\mathrm{z}_{\mathrm{pr}}(\alpha)+\mathrm{z}_{\mathrm{a}}
$$

when $\mathrm{z}_{\mathrm{a}}$ denominates the wear component of constant value, where as $z_{\text {pr }}(\alpha)$ is a wear component resulting from the course of cylinder axial profile given by

$$
z_{\mathrm{pr}}(\alpha)=\frac{\mathrm{z}_{\mathrm{ZZ}} \cdot \mathrm{Z}_{\mathrm{ZW}} \cdot \mathrm{S}}{\left(\mathrm{z}_{\mathrm{ZZ}}-\mathrm{z}_{\mathrm{ZW}}\right) \cdot \mathrm{x}(\alpha)+\mathrm{Z}_{\mathrm{ZW}} \cdot \mathrm{S}}
$$

where $z_{z z}$ and $z_{z W}$ are values of wear at top and bottom dead centers, respectively, $x(\alpha)$ denotes displacement of ring relative to crank angle $\alpha$, while $S$ is the piston stroke. Though the formula of cylinder axial profile (5) is just an approximation of real profile, it allows estimating the effect of its course on ring pressure distribution. When drawing the curves it was assumed that the condition $\mathrm{z}_{\mathrm{zz}} / \mathrm{z}_{\mathrm{ZW}}>10$ is satisfied.

The $K_{z}(\alpha)$ coefficient, further called the dynamic characteristic coefficient of ring, is given by [2]

$$
K_{z}(\alpha)=K+\frac{p_{g}(\alpha) \cdot h_{p} \cdot r_{m}^{3}}{E \cdot I}=K+K_{g}(\alpha)
$$

where $\mathrm{p}_{\mathrm{g}}(\alpha)$ - gas pressure pressing the compression ring on cylinder face (its value depends on gas pressure over and below the ring), changing its value relative to the crank angle $\alpha, \mathrm{K}_{\mathrm{g}}(\alpha)$ - gaseous characteristic coefficient of ring, dependent on engine load, $\mathrm{K}$ - constructional characteristic coefficient of ring

$$
\mathrm{K}=\frac{\mathrm{p}_{\mathrm{m}} \cdot \mathrm{h}_{\mathrm{p}} \cdot \mathrm{r}_{\mathrm{m}}^{3}}{\mathrm{E} \cdot \mathrm{I}}
$$

charakterystyczny pierścienia - równanie (7),

którego wartość zależy od wymiarów nowego pierścienia i jego właściwości materiałowych, natomiast nie odzwierciedla zmian jego właściwości sprężystych, spowodowanych np. zużyciem, obciążeniem cieplnym itp. Przebieg wartości dynamicznego współczynnika charakterystycznego pierścienia, obliczony dla wybranych wartości obciążenia przykładowego silnika, pokazano na rys. 5 .

Jeżeli za miarę właściwości sprężystych pierścienia przyjmie się siłę styczną $F_{t}$ (jest to siła, która działając na końcach swobodnych pierścienia powoduje jego zaciśnięcie i uzyskanie luzu $1_{z}$ - rys. 2a), to współczynnik K można zapisać [5]w postaci równania (8).

Uwzględniając powiązania współczynnika K $\mathrm{z}$ wielkością rozstawu m między końcami swobodnego pierścienia (rys. 2a), które ma postać równania (9), uzyskuje się wyrażenie podawane przez firmę Goetze [4] w postaci wzoru (10),

gdzie C - stała, której wartość dla pierścieni o średnicach bliskich $100 \mathrm{~mm}$ jest równa 14,14.

We wcześniej realizowanych badaniach zakładano, że wartość współczynnika K nie ulega zmianie i odpowiada wartości obliczonej dla nowego pierścienia. Ze wzorów (8) i (10) wynika jednak, że podczas pracy silnika jego wartość będzie się zmniejszała. Przykładowo, zmniejszeniu grubości promieniowej $g_{p}$ pierścienia, spowodowanej np. zużyciem jego powierzchni ślizgowej, będzie towarzyszyć zmniejszenie wartości siły stycznej $\mathrm{F}_{\mathrm{t}}$, a tym samym współczynnika $\mathrm{K}$. Aby oszacować wpływ tego zjawiska na rozkład nacisków, w prezentowanych dalej obliczeniach współczynnik K zastąpiono współczynnikiem K(t), symbolizującym wpływ czasu eksploatacji pierścienia (na początku eksploatacji silnika, dla $\mathrm{t}=0, \mathrm{~K}(\mathrm{t})=\mathrm{K})$.

Ostatecznie, po uwzględnieniu opisanych wcześniej zmian, wzory (1) i (5) przyjmą postać równań (11) i (12).

Obliczenie obwodowego rozkładu nacisków pierścienia pozwala ocenić, czy pierścień na całym swym obwodzie ma kontakt z powierzchnią ślizgową cylindra (jak na rys. 6a) lub czy kontakt ten jest niepełny (rys. 6b).

Powtarzając obliczenia dla kolejnych położeń pierścienia, można otrzymać obraz obwodowego rozkładu nacisków w funkcji kąta obrotu wału korbowego (nazywany dalej także obrazem współpracy). Są na nim widoczne obszary o zróżnicowanym nacisku, w których występuje pełny kon- 
value of which depends on dimensions of new ring and its materials properties, whereas it does not reflect the variations of elastic properties caused by wear, thermal load etc. The course of ring dynamic characteristic coefficient, calculated for chosen values of engine load, has been presented in Fig. 5.

If the tangential force $\mathrm{F}_{\mathrm{t}}$ (force acting on ring free ends brings about their contact and get the clearance $l_{z}$ - see Fig. $2 a)$ would be assumed as the measure of ring elastic properties, the coefficient could be written as follows [5]

$$
\mathrm{K}=\frac{\mathrm{F}_{\mathrm{t}} \cdot \mathrm{r}_{\mathrm{m}}^{2}}{\mathrm{E} \cdot \mathrm{I}}
$$

Taking into consideration relation between the K coefficient and distance between ring free ends $\mathrm{m}$ (see Fig. 2a)

$$
\mathrm{K}=\frac{\mathrm{m}}{3 \cdot \pi \cdot \mathrm{r}_{\mathrm{m}}}
$$

one obtains the formula proposed by the Federal Mogul Goetze company [4]

$$
F_{t}=\frac{E \cdot m \cdot h_{p}}{C \cdot\left(\frac{d}{g_{p}}-1\right)^{3}}
$$

where $\mathrm{C}$ is a constant equal to 14.14 for rings of $100 \mathrm{~mm}$ diameter.

In the earlier studies of the authors it was assumed that the value of $\mathrm{K}$ coefficient does not changes and corresponds to the value calculated for a new ring. However, the equations (8) and (10) show that during engine run its value will decrease. For example, a decrease in ring radial thickness $g_{p}$ caused by the wear of its sliding surface for instance will be accompanied by the decrease in tangential force $F_{t}$, value, and parallel the coefficient $\mathrm{K}$. In order to estimate the effect of this phenomenon on pressure distribution the $\mathrm{K}$ coefficient was substituted by the $\mathrm{K}(\mathrm{t})$ coefficient in further calculations, which takes into account the influence of operational time (at the beginning of engine run $\mathrm{K}(\mathrm{t})=\mathrm{K}$ for $\mathrm{t}=0$ ).

Finally, with the respect for earlier described changes, Eq. (1) and (5) will take the form:

$$
\begin{gathered}
\mathrm{K}_{\mathrm{z}}(\alpha)=\mathrm{K}(\mathrm{t})+\mathrm{K}_{\mathrm{g}}(\alpha) \\
\mathrm{p}_{\mathrm{m}}(\varphi)=\frac{\mathrm{E} \cdot \mathrm{I}}{\mathrm{h}_{\mathrm{p}} \cdot \mathrm{r}_{\mathrm{m}}^{4}} \cdot \\
\cdot\left[\mathrm{K}_{\mathrm{z}}(\alpha) \cdot \mathrm{r}_{\mathrm{m}}-\left(\mathrm{z}_{\mathrm{a}}(\alpha)+\mathrm{z}_{\mathrm{b}}(\varphi)+2 \cdot \mathrm{z}_{\mathrm{b}}^{\prime \prime}(\varphi)+\mathrm{z}_{\mathrm{b}}^{\mathrm{IV}}(\varphi)\right)\right]
\end{gathered}
$$

Calculation of the ring circumferential pressure distribution allows to evaluate if touches the liner surface with its entire circumference (as in Fig. 6a) or this contact is not full (Fig. 6b).

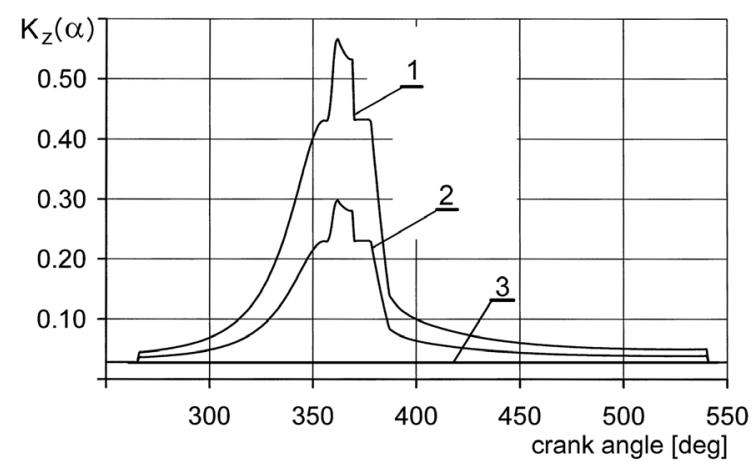

Fig. 5. Course of ring characteristic dynamic coefficient value $K_{z}(\alpha)$ vs. $\alpha$ angle calculated for $\mathrm{K}_{\mathrm{g}}(\alpha)=100 \%$ (1), 50\% (2) and $0 \%$ (3) load [6] Rys. 5. Przebieg wartości dynamicznego wspótczynnika charakterystycznego pierścienia $K_{z}(\alpha)$ w funkcji kąta $\alpha$ wyznaczony dla petnego $K_{g}(\alpha)=$ 100\% (1), 50\% (2) i 0\% (3) obciążenia silnika [6]

takt współpracujących elementów oraz takie, w których tego kontaktu brakuje $\left(\operatorname{gdy} \mathrm{p}_{\mathrm{m}}(\varphi)<0\right)$. Do ilościowego opisu tego zjawiska wprowadzono wielkość P, którą nazwano współczynnikiem poprawności współpracy pierścienia z gładzią cylindra - równanie (13),

gdzie: $\mathrm{P}_{\mathrm{c}}$ - powierzchnia równa powierzchni gładzi cylindra, położona pomiędzy punktami zwrotnymi (pominięto obszar zamka pierścienia), $\mathrm{P}_{\mathrm{b}}$ - powierzchnia, na której brak jest kontaktu pierścienia $\mathrm{z}$ gładzią cylindra.

Wartość współczynnika P mniejsza od 100\% oznacza, że istnieją obszary (obszar) na gładzi cylindra, w których w wyniku brak kontaktu powstają szczeliny, przez które mogą wystąpić przedmuchy gazów. Chociaż w opisanych dalej obliczeniach nie wyznaczano geometrii szczeliny, to orientacyjnie można przyjąć, że wielkość przedmuchów będzie wzrastała wraz z obniżaniem się wartości współczynnika $P$.

\section{Wyznaczanie nacisku pierścienia uszczelniającego na gładź odkształconego cylindra}

\subsection{Wprowadzenie}

Realizacja opisanych dalej badań miała na celu uzyskanie informacji o wpływie wybranych wielkości, charakteryzujących geometrię pierścienia i cylindra oraz warunki ich pracy, na rozkład nacisków pierścienia na gładź na całej drodze jego przemieszczania się między punktami zwrotnymi. W obliczeniach uwzględniono:

- zużycie gładzi $z_{\mathrm{a}}(\alpha)$ mierzone wzdłuż obwodu i profilu cylindra,

- deformacje gładzi $z_{b}(\varphi)$, opisane harmonicznymi 2., 4. i 6. rządu.

Poza zmianami geometrii cylindra uwzględniono także:

- zmiany wartości sił gazowych, charakteryzowane przez współczynnik $\mathrm{K}_{\mathrm{g}}(\alpha)$,

- zmiany właściwości sprężystych pierścienia, charakteryzowane przez współczynnik K(t).

Duża liczba uwzględnionych w badaniach wielkości i zróżnicowanie przyjmowanych przez nie wartości spowo- 
a)

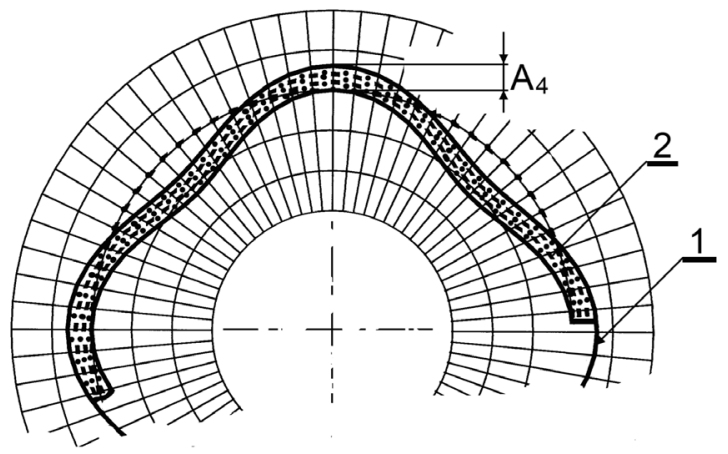

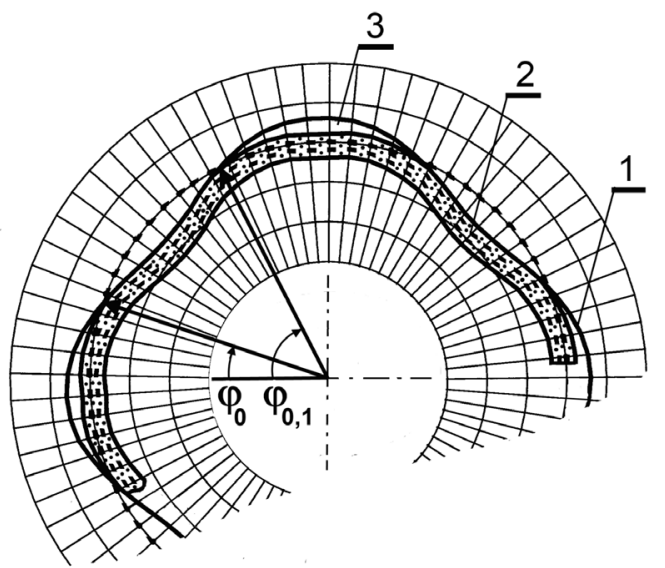

Fig. 6. A sketch illustrating possible positions of ring in deformed bore; 1 - cylinder bore, 2 - ring running face, 3 - slot Rys. 6. Szkic obrazujący możliwe ułożenia pierścienia w zdeformowanym cylindrze: 1 - powierzchnia cylindra, 2 - powierzchnia ślizgowa pierścienia, 3 - szczelina

Repeating these calculations for consecutive positions of ring one can obtain an image of pressure circumferential distribution vs. crank angle (called further the image of collaboration). Areas of diverse pressure are visible where full contact of collaborating parts takes place and other where this contact does not occurs (where $\left.\mathrm{p}_{\mathrm{m}}(\varphi)<0\right)$.

In order to describe quantitatively this phenomenon a parameter $\mathrm{P}$ was proposed, called coefficient of correct collaboration between ring and cylinder bore surface

$$
\mathrm{P}=\frac{\mathrm{P}_{\mathrm{c}}-\mathrm{P}_{\mathrm{b}}}{\mathrm{P}_{\mathrm{c}}} \cdot 100 \%
$$

where $P_{c}$ - entire area of cylinder bore between dead centers (except the area of ring gap), $\mathrm{P}_{b}$-area of no contact between ring and cylinder bore.

If the value of coefficient $P$ is lower than $100 \%$ it means that there is an area over cylinder bore where slots can emerge and eventual blow by occurs. Though slot geometry has not been established in calculations described further, it can be assumed approximately that the blow by will increase along with decrease of the P coefficient.

\section{Determination of compression ring pressure on deformed bore}

\subsection{Introduction}

Implementation of further described research effect of selected quantities characterizing the ring and bore geometry as well as conditions of their collaboration on distribution of ring pressure on bore within entire stroke between dead centers. Calculation took into account:

- bore wear $\mathrm{z}_{\mathrm{a}}(\alpha)$ measured along the bore circumference and profile,

- bore deformation $\mathrm{z}_{\mathrm{b}}(\varphi)$, described with the harmonics of $2^{\text {nd }}, 4^{\text {th }}$ and $6^{\text {th }}$ order.

In addition to changes in bore geometry following quantities have been taken into account: dowały, że w miejscu kompletnego planu badań wybrano plan monoselekcyjny. Mimo tego ograniczenia wygenerowano dużą liczbę wyników, trudną do pełnego zaprezentowania w tym opracowaniu - przedstawiono jedynie najważniejsze z nich. Chociaż obliczenia wykonano dla pełnego cyklu pracy silnika, zaprezentowane wyniki obejmują jedynie fragment gładzi cylindra (zawarty pomiędzy kątami $\varphi$ od $0,25 \pi$ do $0,75 \pi)$ i dotyczą tylko suwu sprężania.

Obliczenia wykonano, wykorzystując dane techniczne wysokoprężnego silnika spalinowego pracującego w maszynie roboczej. Tego samego silnika dotyczyły obliczenia zawarte w kilku innych publikacjach autorów, np. [7-9].

Najważniejsze wyniki i ich krótkie omówienie zawarto w dwóch kolejnych podrozdziałach, przy czym oddzielnie przedstawiono wpływ wielkości związanych z cylindrem i z tłokowym pierścieniem uszczelniającym.

\subsection{Wpływ zużycia gładzi cylindra na rozkład nacisku pierścienia}

W pierwszym etapie prezentowanych tu badań obliczono rozkład nacisku wywierany na gładź przez nowy pierścień uszczelniający $(\mathrm{K}(\mathrm{t})=\mathrm{K})$ przy założeniu, że nie działają nań siły gazowe $\left(\mathrm{K}_{\mathrm{g}}(\alpha)=0\right)$. Podczas obliczeń zmieniano wartości wielkości charakteryzujących zużycia cylindra, tj. $z_{a}(\alpha)$ i $z_{b}(\varphi)$. Poza rozkładem nacisku obliczano także parametr $P$.

Obrazy rozkładu nacisku, pokazane na rys. 7, dotyczą przypadku współpracy nowego pierścienia z cylindrem o zdeformowanej powierzchni, którego linię obwodową można opisać harmoniczną 6. rzędu. Chociaż początkowo deformacja ta nie pogarsza w widoczny sposób poprawności tej współpracy (rys. 7a), to wraz ze wzrostem zużycia gładzi, zarówno obwodowego, jak i osiowego, powiększają się obszary, w których pierścień nie przylega na całym swoim obwodzie do gładzi (rys. 7b-d). Widoczna jest prawidłowość, że wraz ze wzrostem zużycia gładzi, zarówno promieniowego, jak i osiowego, zmniejsza się nacisk pierścienia na gładź, powodując zmniejszanie się 
- changes in gas force values, characterized by the $\mathrm{K}_{\mathrm{g}}(\alpha)$ coefficient,

- changes in ring elastic properties, characterized by the $\mathrm{K}(\mathrm{t})$ coefficient.

A high number of quantities taken into consideration and variety of their values made that instead of a complete plan of investigations the authors decided to use a monoselective plan. Despite this limitation a high number of results have been generated, impossible to be presented in one paper. This have made authors to present only the most important of them. Although the computations have been carried out for a full cycle of engine operation, the results presented here encompass only a section of cylinder bore (for $\varphi$ angle between $0,25 \pi$ and $0,75 \pi$ - compression stroke).

Computations have been carried out using technical data of work machine driving diesel. Calculations presented in the earlier papers of the authors [for example 8,9] concerned the same engine.

The most important results and their brief comment will be presented in successive chapters, where the effects connected with cylinder bore and compression ring would be presented separately.

\subsection{Cylinder bore wear effect on ring pressure distribution}

At the first stage of research a new ring pressure distribution $(\mathrm{K}(\mathrm{t})=\mathrm{K})$ on cylinder bore have been calculated, assuming that there is no gas force $(\operatorname{Kg}(\alpha)=0)$. Values characteristic for cylinder wear, i.e. $z_{a}(\alpha)$ and $z_{b}(\beta)$ were changed during calculations. Beside pressure distribution the P parameter was calculated as well.

Pressure distribution images seen in Fig. 7 concern the case of new ring collaboration with cylinder bore of deformed surface, illustrated by the circumferential line described with the harmonic of $6^{\text {th }}$ order. Though initially this deformation does not make visibly such collaboration worse (Fig. 7a), but with the increase in bore wear, both axial and circumferential, areas where ring losses its contact with bore along the entire circumference become greater (Fig. 7b-d).

A regularity can be noticed that along with the increased wear of bore at the same time the ring pressure decreases

a)
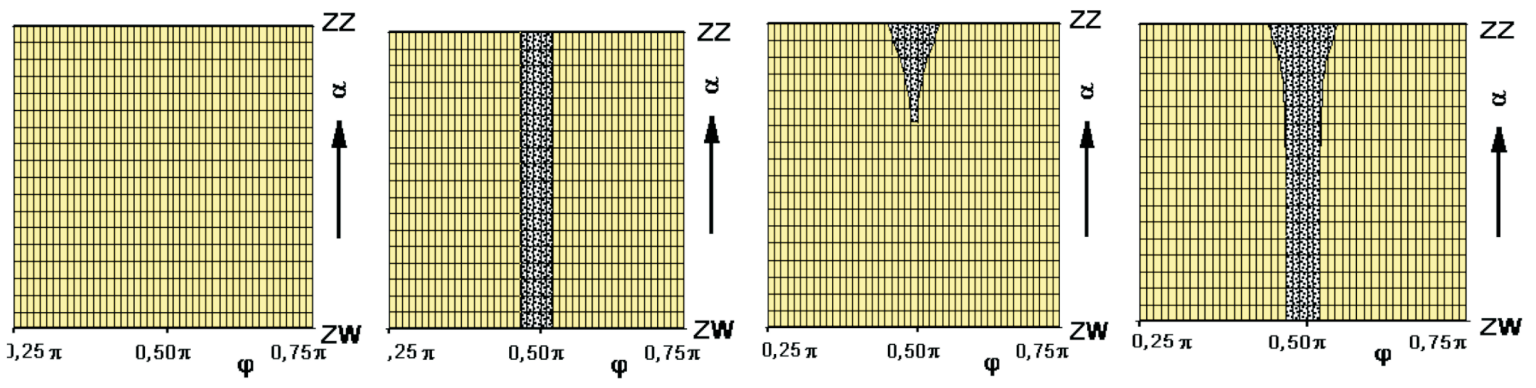

Jak wynika z wcześniejszych rozważań, oddziaływanie sił gazowych powinno powodować pełniejszy obwodowy kontakt pierścienia z odkształconą gładzią cylindra. Aby sprawdzić tą współzależność, w drugim etapie badań powtórzono prezentowane wcześniej obliczenia, jednak z uwzględnieniem sił gazowych odpowiadających pracy silnika przy jego pełnym obciążeniu (krzywa 1 na

Fig. 7. Images of ring contact pressure distribution during piston move towards TDC, calculated for $\mathrm{K}_{\mathrm{g}}(\alpha)=0, \mathrm{z}_{\mathrm{b}}(\varphi) \neq 0\left(\mathrm{~A}_{6}=1.2 \mu \mathrm{m}\right)$, when: Rys. 7. Obrazy rozkładu nacisku pierścienia na gładź cylindra podczas ruchu tłoka w kierunku ZZ, wyznaczone dla $K_{g}(\alpha)=0, z_{b}(\varphi) \neq 0\left(A_{6}=1,2 \mu m\right)$, gdy: a) $\left.\left.\left.\mathrm{z}_{\mathrm{a}}=0 \mu \mathrm{m}, \mathrm{z}_{\mathrm{pr}}(\alpha)=0, \mathrm{P}=100 \%, \mathrm{~b}\right) \mathrm{z}_{\mathrm{a}}=200 \mu \mathrm{m}, \mathrm{z}_{\mathrm{pr}}(\alpha)=0, \mathrm{P}=91 \%, \mathrm{c}\right) \mathrm{z}_{\mathrm{a}}=0 \mu \mathrm{m}, \mathrm{z}_{\mathrm{pr}}(\alpha) \neq 0\left(\mathrm{z}_{\mathrm{G}}=500 \mu \mathrm{m}\right), \mathrm{P}=98 \%, \mathrm{~d}\right) \mathrm{z}_{\mathrm{a}}=200 \mu \mathrm{m}, \mathrm{z}_{\mathrm{pr}}(\alpha) \neq 0$ $\left(\mathrm{z}_{\mathrm{zz}}=500 \mu \mathrm{m}\right), \mathrm{P}=89 \%$ 
a)

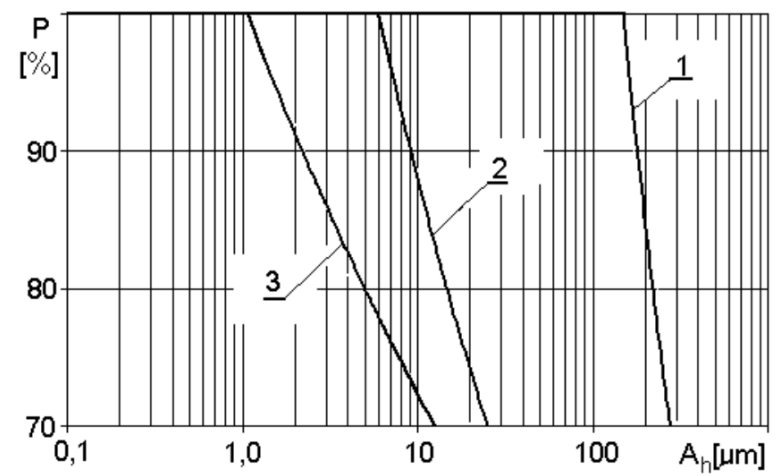

b)

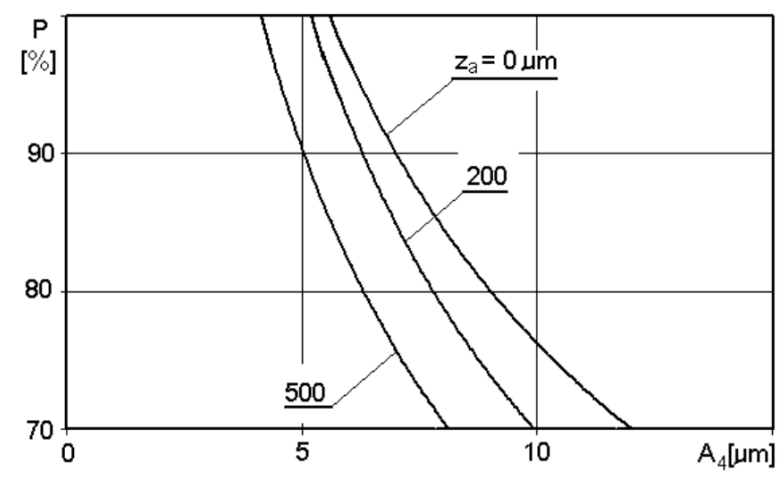

Fig. 8. Changes in coefficient $P$ value relative to the size of cylinder deformation described with the $2^{\text {nd }}$ order (curve 1$)$, $4^{\text {th }}$ order (curve 2$)$ and $6^{\text {th }}$ order (curve 3 ) harmonic, calculated for $\mathrm{K}_{\mathrm{g}}(\alpha)=0$ (a) and relative to the bore circumferential wear value $\mathrm{z}_{\mathrm{a}}$ (for deformation described with the $4^{\text {th }}$ order harmonic) (b)

Rys. 8. Zmiany wartości wspótczynnika P w zależności od wielkości deformacji cylindra opisanej harmoniczna 2 rzędu (krzywa 1), 4 rzędu (krzywa 2) i 6 rzędu (krzywa 3), wyznaczone dla $K_{g}(\alpha)=0$ (a) oraz $w$ zależności od wartości zużycia obwodowego gładzi $z_{a}$ (dla odkształcenia opisanego harmoniczna 4 rzędu) (b)

which leads to decrease in areas of correct collaboration that means lower value of the $\mathrm{P}$ coefficient.

Graphs in Fig. 8 show the effect of harmonic's order and amplitude on the P coefficient values. Higher order of analyzed harmonic the loss of contact between ring and bore occurs at lower value of harmonic's amplitude. This effect increases along with increasing wear of bore (it results from the course of curves in Fig. 8b obtained for the cylinder bore profile described with the $4^{\text {th }}$ order harmonic).

The earlier analyses suggest that the effect of gas forces should cause a more complete circumferential contact of ring and deformed cylinder bore. At the second stage of investigations the earlier presented calculations were repeated, but taking into account the gas forces corresponding to the engine operation at full load (curve 1 in Fig. 5), in order to verify this interdependence. Fig. 9 shows the achieved images of collaboration and values of the P coefficient. As one could anticipate the influence of gas forces improves the ability of ring to bore contact, however the negative effect is an increase in pressure differentiation, which could result in ring breaking when the bore deformations are significant (Fig. 10). rys. 5). Na rysunku 9 przedstawiono uzyskane obrazy współpracy i zestawiono wartości współczynnika P. Jak należało się spodziewać, oddziaływanie sił gazowych poprawia zdolność przylegania pierścienia do gładzi cylindra, jednak ujemnym skutkiem ich działania jest wzrost zróżnicowania nacisku, co przy dużych amplitudach odkształcenia gładzi może prowadzić do pękania pierścieni (rys. 10).

Zbiorcze zestawienie krzywych, uwzględniające wpływ rzędu harmonicznej deformacji i jej amplitudy na wartość współczynnika P, opracowane dla braku oraz pełnego obciążeniu silnika, pokazano na rys. $11 \mathrm{a}$. $\mathrm{Z}$ ich przebiegu wynika, że we wszystkich analizowanych przypadkach działanie gazów spalinowych wpływa na powiększenie obszaru poprawnej współpracy pierścienia z gładzią cylindra, natomiast zużycie gładzi ten obszar zmniejsza (rys. 11b). Powiększeniu ulega także wartość amplitudy harmonicznej, zapewniającej jeszcze poprawny przebieg współpracy tych elementów. a)

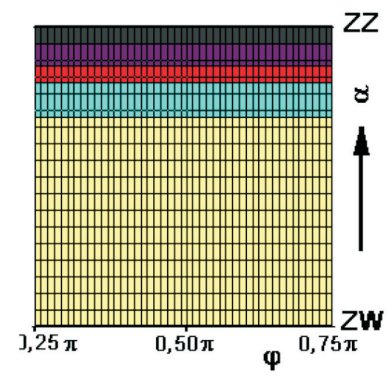

b)

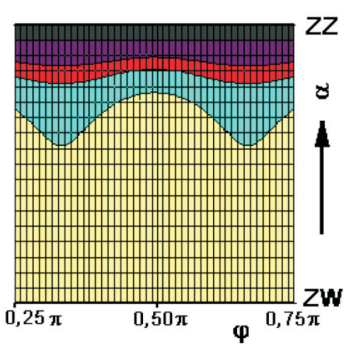

c)

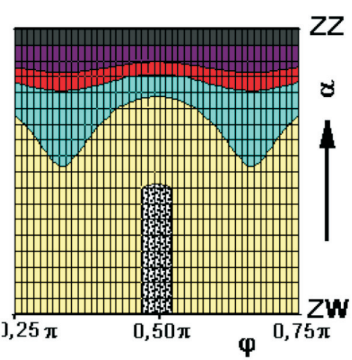

d)

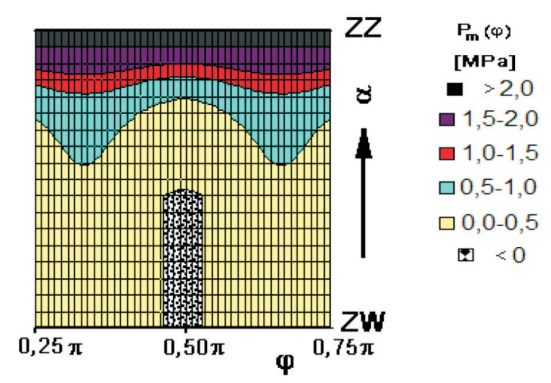

Fig. 9. Images of ring contact pressure distribution during piston move towards TDC, calculated for $\mathrm{K}_{\mathrm{g}}(\alpha)=100 \%$, when: Rys. 9. Obrazy rozkładu nacisku pierścienia na gładź cylindra podczas ruchu tłoka w kierunku ZZ, wyznaczone dla $K_{g}(\alpha)=100 \%$, dla: a) $\left.\left.\mathrm{z}_{\mathrm{a}}=0 \mu \mathrm{m}, \mathrm{z}_{\mathrm{b}}(\varphi)=0 \mu \mathrm{m}, \mathrm{z}_{\mathrm{pr}}(\alpha)=0, \mathrm{P}=100 \%, \mathrm{~b}\right) \mathrm{z}_{\mathrm{a}}=200 \mu \mathrm{m}, \mathrm{z}_{\mathrm{b}}(\varphi) \neq 0\left(\mathrm{~A}_{6}=1.2 \mu \mathrm{m}\right), \mathrm{z}_{\mathrm{pr}}(\alpha)=0, \mathrm{P}=100 \%, \mathrm{c}\right) \mathrm{z}_{\mathrm{a}}=0 \mu \mathrm{m}, \mathrm{z}_{\mathrm{b}}(\varphi) \neq 0\left(\mathrm{~A}_{6}=1.2 \mu \mathrm{m}\right)$, $\left.\mathrm{z}_{\mathrm{pr}}(\alpha) \neq 0\left(\mathrm{z}_{\mathrm{zz}}=500 \mu \mathrm{m}\right), \mathrm{P}=97 \%, \mathrm{~d}\right) \mathrm{z}_{\mathrm{a}}=200 \mu \mathrm{m}, \mathrm{z}_{\mathrm{b}}(\varphi) \neq 0\left(\mathrm{~A}_{6}=1.2 \mu \mathrm{m}\right), \mathrm{z}_{\mathrm{pr}}(\alpha) \neq 0\left(\mathrm{z}_{\mathrm{zz}}=500 \mu \mathrm{m}\right), \mathrm{P}=92 \%$ 
a)

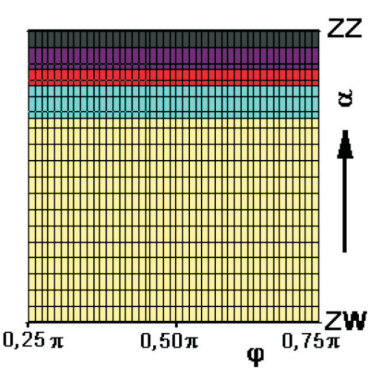

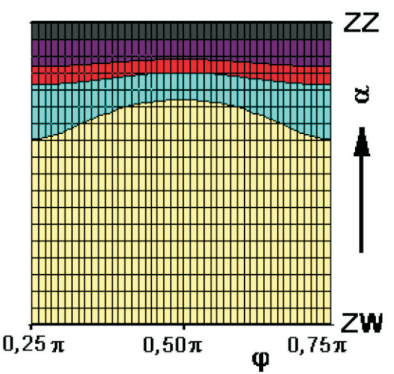

c)

Fig. 10. Images of ring contact pressure distribution during piston move towards TDC, calculated for $\mathrm{K}_{\mathrm{g}}(\alpha)=100 \%, \mathrm{z}_{\mathrm{a}}=0 \mu \mathrm{m}, \mathrm{z}_{\mathrm{pr}}(\alpha)=0$, when: Rys. 10. Obrazy rozkładu nacisku pierścienia na gładź cylindra podczas ruchu tłoka $w$ kierunku ZZ, wyznaczone dla $K_{g}(\alpha)=100 \%, z_{a}=0 \mu m, z_{p r}(\alpha)=0, \%$, dla: a) $\left.\left.\left.\mathrm{z}_{\mathrm{b}}(\varphi)=0 \mu \mathrm{m}, \mathrm{P}=100 \%, \mathrm{~b}\right) \mathrm{z}_{\mathrm{b}}(\varphi) \neq 0\left(\mathrm{~A}_{4}=5 \mu \mathrm{m}\right), \mathrm{P}=100 \%, \mathrm{c}\right) \mathrm{z}_{\mathrm{b}}(\varphi) \neq 0\left(\mathrm{~A}_{4}=10 \mu \mathrm{m}\right), \mathrm{P}=88 \%, d\right) \mathrm{z}_{\mathrm{b}}(\varphi) \neq 0\left(\mathrm{~A}_{4}=30 \mu \mathrm{m}\right), \mathrm{P}=67 \%$
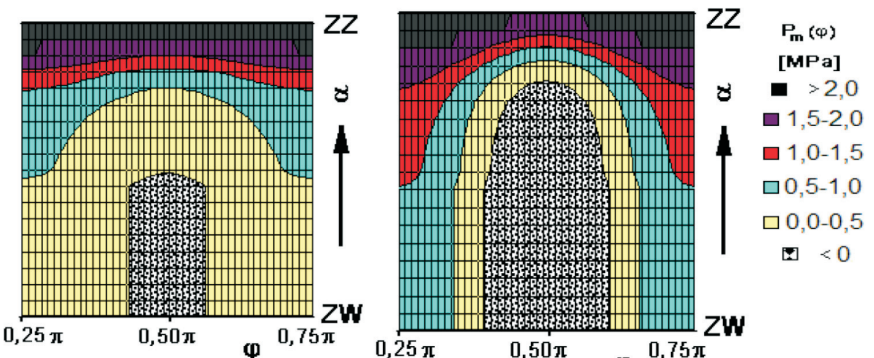

b)
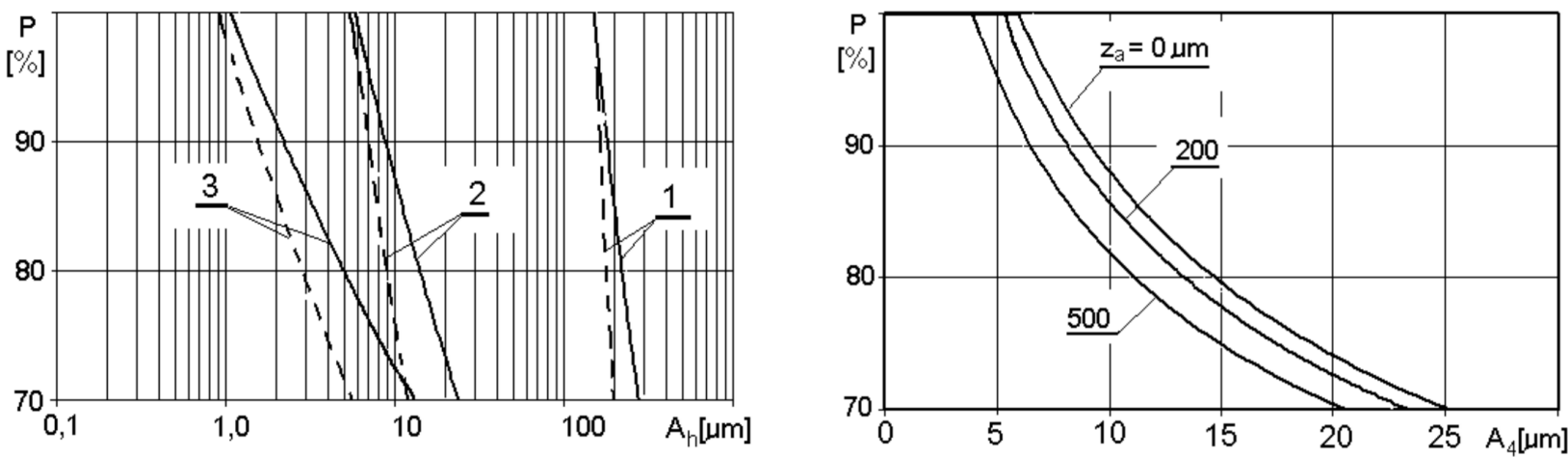

Fig. 11. Changes in coefficient P value relative to: $a-$ bore deformation size described with $2^{\text {nd }}$ order $($ curve 1$)$, $4^{\text {th }}$ order $($ curve 2$)$ and $6^{\text {th }}$ order harmonic (curve 3 ), calculated for $\mathrm{K}_{\mathrm{g}}(\alpha)=100 \%$ (continuous line) and for $\mathrm{K}_{\mathrm{g}}(\alpha)=0$ (dashed line), $\mathrm{b}$ - bore circumferential wear described by $4^{\text {th }}$ order harmonic

Rys. 11. Zmiany wartości współczynnika P w zależności od: a-wartości deformacji cylindra opisanej harmoniczna 2 rzędu (krzywa 1), 4 rzędu (krzywa 2) i 6 rzędu (krzywa 3), wyznaczone dla $K_{g}(\alpha)=100 \%$ (linia ciagła) oraz dla $K_{g}(\alpha)=0$ (linia kreskowa), b-wartości zużycia obwodowego gładzi cylindra opisana harmoniczna 4 rzędu

A comparison of curves, taking into account the effect of deformation harmonic order and amplitude on the value of $P$ coefficient, prepared for cases of engine idle run and full load are presented in Fig. 11a. Their course shows that in each presented case operation of exhaust gases increases the area of correct collaboration of ring and bore, while the degree of bore wear makes this area smaller (Fig. 11b).

Their course shows that in each presented case operation of exhaust gases increases the area of correct collaboration of ring and bore, while the degree of bore wear makes this area smaller (Fig. 11b). The value of harmonic amplitude which still provides a correct collaboration of parts increases as well.

\subsection{The effect of compression ring wear}

As it follows from the Eq. (10) the wear of ring face and deterioration of its materials properties leads to the decrease in tangential force $\mathrm{F}_{\mathrm{t}}$ and simultaneously to the decrease in ring pressure against the bore. Independently on the cause of this phenomenon, the coefficient $\mathrm{K}(\mathrm{t})$ was adopted as the

\subsection{Wpływ zużycia pierścienia uszczelniającego}

Jak wynika ze wzoru (10), zużycie powierzchni roboczych pierścienia oraz pogorszenie jego właściwości materiałowych powoduje zmniejszenie wartości siły stycznej $\mathrm{F}_{\mathrm{t}}$ i tym samym zmniejszenie docisku pierścienia do gładzi cylindra. Za miarę utraty właściwości sprężystych pierścienia, niezależnie od przyczyny tego zjawiska, przyjęto współczynnik $\mathrm{K}(\mathrm{t})$. W tym etapie badań dokonano próby oceny wpływu obniżenia wartości tego współczynnika na zdolność przylegania pierścienia do gładzi, zmniejszając jego wartość o odpowiednio 10\% i 20\%. Niektóre z uzyskanych wyników podano na rys. $12 \mathrm{i} 13$.

Porównanie obrazów współpracy (rys. 7 i 12) oraz wartości współczynnika $\mathrm{P}$ umożliwia stwierdzenie, że wraz z pogorszeniem właściwości sprężystych pierścienia zmniejsza się obszar poprawnej współpracy pierścienia z gładzią cylindra.

Pełniejszą ocenę tej współzależności umożliwia analiza przebiegów zestawionych na wykresie rys. 13. Wynika 
a)

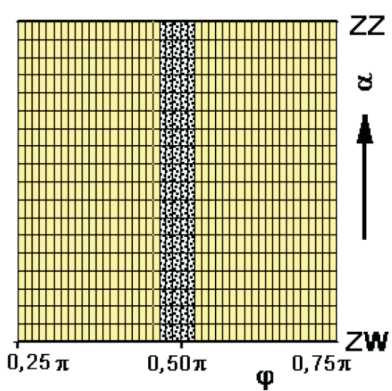

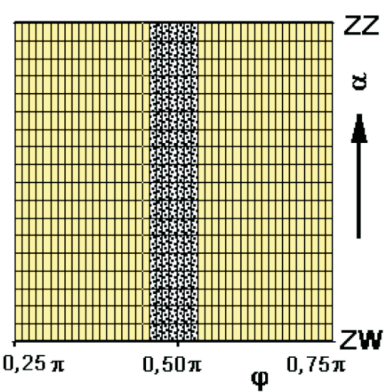

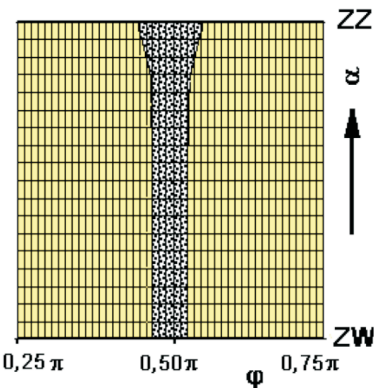

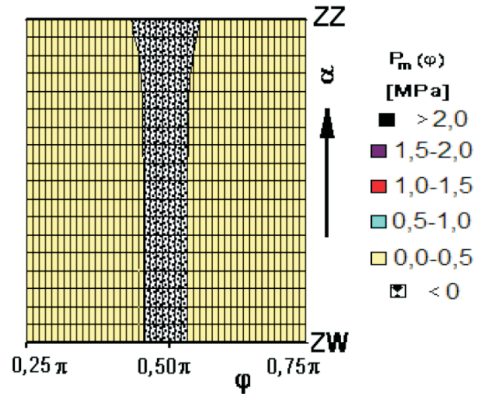

Fig. 12. Images of ring contact pressure distribution during piston move towards TDC, calculated for $\mathrm{K}_{\mathrm{g}}(\alpha)=0, \mathrm{z}_{\mathrm{b}}(\varphi) \neq 0\left(\mathrm{~A}_{6}=1.2 \mu \mathrm{m}\right)$, and the value of coefficient $\mathrm{K}(\mathrm{t})$ reduced by $10 \%$, when:

Rys. 12. Obrazy rozkładu nacisku pierścienia na gładź cylindra podczas ruchu tłoka $w$ kierunku $Z Z$, wyznaczone dla $K_{g}(\alpha)=0, z_{b}(\varphi) \neq 0\left(A_{6}=1,2 \mu m\right)$, i zmniejszonej o $10 \%$ wartości współczynnika $K(t)$, dla:

a) $\left.\left.\left.\mathrm{z}_{\mathrm{a}}=0 \mu \mathrm{m}, \mathrm{z}_{\mathrm{pr}}(\alpha)=0, \mathrm{P}=96 \%, \mathrm{~b}\right) \mathrm{z}_{\mathrm{a}}=200 \mu \mathrm{m}, \mathrm{z}_{\mathrm{pr}}(\alpha)=0, \mathrm{P}=91 \%, \mathrm{c}\right) \mathrm{z}_{\mathrm{a}}=0 \mu \mathrm{m}, \mathrm{z}_{\mathrm{pr}}(\alpha) \neq 0\left(\mathrm{z}_{\mathrm{zz}}=500 \mu \mathrm{m}\right), \mathrm{P}=93 \%, \mathrm{~d}\right) \mathrm{z}_{\mathrm{a}}=200 \mu \mathrm{m}, \mathrm{z}_{\mathrm{pr}}(\alpha) \neq 0$ $\left(\mathrm{z}_{\mathrm{zz}}=500 \mu \mathrm{m}\right), \mathrm{P}=85 \%$

a)

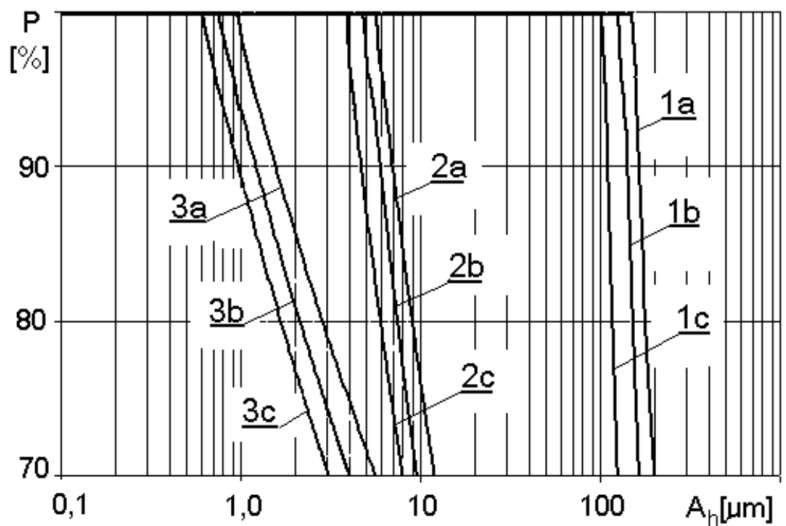

b)

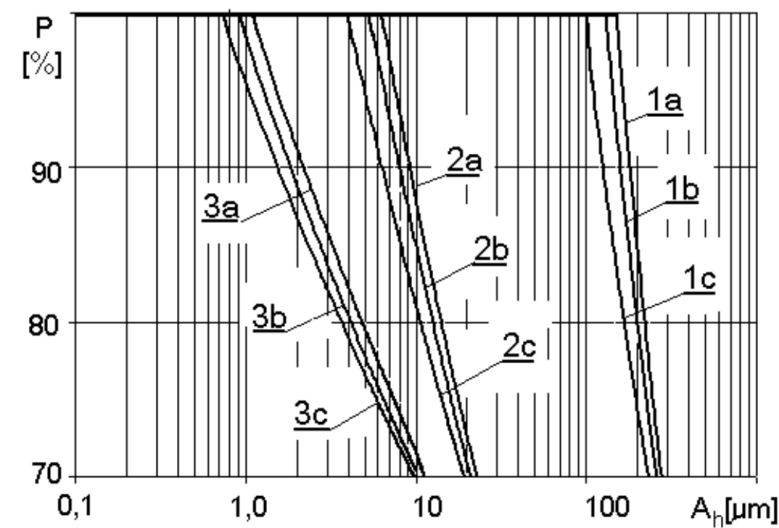

Fig. 13. Changes in coefficient $P$ value relative to amplitude of bore deformation described with $2^{\text {nd }}$ order (curve 1$), 4^{\text {th }}$ order (curve 2$)$ and $6^{\text {th }}$ order (curve 3) harmonic, calculated: $\mathrm{a}-$ for $\mathrm{K}_{\mathrm{g}}(\alpha)=0$ and $\mathrm{K}(\mathrm{t})=\mathrm{K}(\mathrm{a}), \mathrm{K}(\mathrm{t})=0.9 \mathrm{~K}(\mathrm{~b})$ and $\mathrm{K}(\mathrm{t})=0.8 \mathrm{~K}(\mathrm{c}), \mathrm{b}-$ for $\mathrm{K}(\alpha)=100 \%$ and $\mathrm{K}(\mathrm{t})=\mathrm{K}(\mathrm{a}), \mathrm{K}(\mathrm{t})=$ $0.9 \mathrm{~K}(\mathrm{~b})$ and $\mathrm{K}(\mathrm{t})=0.8 \mathrm{~K}(\mathrm{c})$

Rys. 13. Zmiany wartości współczynnika P w zależności od amplitudy deformacji cylindra opisanej harmoniczna 2 (krzywa 1), 4 (krzywa 2) i 6 (krzywa 3) rzadu, wyznaczone przy: $a-d l a K_{g}(\alpha)=0 i K(t)=K(a), K(t)=0,9 K(b) i K(t)=0.8 K(c), b-d l a K(\alpha)=100 \% i K(t)=K(a), K(t)=0,9 K$ (b) $i K(t)=0.8 K(c)$

measure of the loss of ring elastic properties. At this stage of research a trial to evaluate the effect of this coefficient decrease on ring contact ability was performed, decreasing its value by $10 \%$ and $20 \%$, respectively. Some of achieved results are presented in Figs. 12 and 13.

The comparison of collaboration images (Fig. 7 and 11) and values of the P coefficient allows to conclude that together with the deterioration of ring elastic properties an area of correct collaboration of ring face and cylinder bore diminishes as well.

The analysis of courses summarized in Fig. 13 allows to evaluate this interdependence more completely. This analysis shows that independently on the order of harmonic describing the form of bore deformation as well as its amplitude, the deterioration of ring elastic properties always is accompanied by the decrease in the $\mathrm{P}$ coefficient. z niej, że niezależnie od rzędu harmonicznej opisującej postać deformacji cylindra jak i jej amplitudy pogorszeniu właściwości sprężystych pierścienia zawsze towarzyszy spadek wartości współczynnika P.

\section{Podsumowanie i wnioski}

Wyniki przykładowych obliczeń wskazują na silne powiązanie kształtu otworu cylindra i sprężystości pierścienia $\mathrm{z}$ rozkładem nacisków. W szczególności stwierdzono, że:

- deformacje cylindra mają duży wpływ na rozkład nacisku, przy czym im wyższy jest rząd harmonicznej opisującej deformację, tym mniejsza wartość amplitudy powoduje powstanie dużego zróżnicowania nacisku,

- zarówno wzrost promieniowego, jak i osiowego zużycia gładzi powodują spadek nacisku pierścienia, jednak nawet 


\section{Summary and conclusions}

The results of exemplary calculations show a close relation between cylinder bore shape and ring elasticity with distribution of ring pressure. Following observations were done:

- deformations of cylinder bore affect to the far extent a pressure distribution, while higher order of harmonic describing deformation lower value of amplitude causes a significant diversity of pressure,

- increase of both radial and axial wear lead to the reduction in ring pressure, however even high values of wear give relatively low fall in pressure,

- an increase in gas forces causes the increase in ring to bore pressure,

- a decrease in ring elasticity results in reduction of ring pressure.

In extreme case the pressure drop leads to a lack of contact between ring and bore, i.e. possibility of formation of circumferential slots occurs. The method described in this paper allows forecasting such situation because of calculating favorable conditions. Nevertheless one should remember that the presented investigations were carried out assuming the lack of lubricating oil layer (oil film) separating collaborating ring face and cylinder bore. On an operating engine the oil film separates these surfaces eliminating or at least reducing the effect of deformations and micro unevenness. This means that when analyzing the compression ring pressure distribution the influence of microscopic deformations can be neglected, whereas research should take into consideration the deformations of high grade (given by the harmonics of lower order). jego duże wartości wywołują względnie mały spadek nacisku,

- wzrost wartości sił gazowych powoduje wzrost docisk pierścienia do gładzi cylindra,

- pogorszenie właściwości sprężystych pierścienia zmniejsza jego nacisk na gładź cylindra.

Zmniejszenie nacisku w skrajnym przypadku prowadzi do braku kontaktu pierścienia z gładzią cylindra, powodując możliwość powstania szczelin obwodowych. Opisana tu metoda umożliwia obliczenie warunków, przy których sytuacja taka może się pojawić. Należy jednak pamiętać, że przedstawione badania przeprowadzono przy założeniu braku warstwy oleju (filmu olejowego) rozdzielającej współpracujące powierzchnie robocze pierścienia i cylindra. W pracującym silniku film olejowy, tworząc warstwę nośną o grubości od ułamka do nawet kilkunastu mikrometrów, rozdziela te powierzchnie, eliminując lub znacznie ograniczając wpływ mikronierówności i deformacji. Oznacza to, że przy analizie rozkładu nacisku pierścienia uszczelniającego na gładź cylindra wpływ tych niewielkich odkształceń może być pominięty, natomiast badania powinny obejmować wpływ odkształceń o dużej wartości (danych harmonicznymi niższego rzędu).

\section{Bibliography/Literatura}

[1] Bardzimashvili T., Kell J., Romelashvili E. Distortion inside a piston bore. Michigan State University MTH 844, 2004.

[2] Mittler R., Mierbach A., Richardson D. Understanding the Fundamentals of piston ring axial motion and twist and the effects on blow-by. Proceedings of the Internal Combustion Engine Division ASME, ICES2009-76080.

[3] Piaseczny L. Technologia naprawy okrętowych silników spalinowych. Wydawnictwo Morskie, Gdańsk 1992.

[4] Piston Ring Manual. Published by Goetze.

[5] Serdecki W. Analysis of relations between the compression ring characteristic parameters. Journal of POLISH CIMAC. Energetic aspects, Gdańsk 2011, Vol. 6, No. 2.

Wojciech Serdecki, DSc., DEng. - Professor in the Faculty of Mechanical Engineering at Poznań University of Technology.

Dr hab. inż. Wojciech Serdecki, prof. PP - profesor na Wydziale Maszyn Roboczych i Transportu Politechniki Poznańskiej.

e-mail:wojciech.serdecki@put.poznan.pl
[6] Serdecki W., Krzymien P. How the wear of cylinder liner affects the cooperation of piston-cylinder assembly of ic engine. Journal of Kones, Warsaw 2012.

[7] Serdecki W., Krzymień P. An analysis of phenomena accompanying ring collaboration with worn cylinder surface. Combustion Engines, No. 2/2013.

[8] Serdecki W. Variability of compression ring pressure against the deformed cylinder wall during engine operation. Journal of POLISH CIMAC Energetic aspects, Gdańsk 2013, Vol. 8.

[9] Serdecki W., Krzymień P. Analysis of parameters variability of compression ring and cylinder collaboration during engine operation. Journal of POLISH CIMAC Energetic aspects, Gdańsk 2014, Vol. 9.

Piotr Krzymień, DEng. - Assistant professor in the Faculty of Mechanical Engineering at Poznań University of Technology.

Dr inż. Piotr Krzymień - adiunkt na Wydziale Maszyn Roboczych i Transportu Politechniki Poznańskiej. e-mail: piotr.krzymien@put.poznan.pl 